\title{
Physico-chemical Analysis of an Ultisol Polluted with Different Petroleum Products Treated with Poultry Droppings and Planted with Maize in Benin City, Nigeria.
}

\author{
1 Molindo W.A., ${ }^{1}$ Usifo A.E and ${ }^{2}$ Akoma, 0.C.
}

\begin{abstract}
Physicochemical analyses were carried out on an ultisol previously polluted with different petroleum products and later treated with poultry droppings than planted with poultry droppings then planted with maize in the Teaching and research Farm of Benson Idahosa University, Benin City Nigeria. Physicochemical analysis was done on the soil before application different petroleum products (AGO-Automatic gas oil; PMS-Premium motor spirit; DPK-Domestic petroleum kerosene) to the soil. Results showed that the applied products probably contributed to decrease in physicochemical properties of the ultisol when compared to their values before application. Plots applied with AGO had the lowest values followed by PMS and DPK, indicating that AGO might have produced the most degrading effect on the soil. Application of poultry droppings encouraged increased values in physicochemical properties of the soil in all the soils previously applied with petroleum products. This was confirmed when these values were compared with those of the polluted soil and those obtained before pollution. The findings showed that poultry droppings probably encouraged the highest values in soils applied with DPK followed by PMS and AGO respectively. Maize growth estimated in terms of plant height and biomass was highest in bioremediated plots when compared to plants in the control plots.
\end{abstract}

Keywords: Physicochemical , Ultisol, Pollution, Petroleum Products, Poultry Droppings, Maize, Nigeria.

\section{Introduction}

n southern Nigeria and some parts
of the humid tropics, the ultisols are subjected to a regime of high rainfall intensity and degradation. these result in a decline in their productivity. When petroleum products are spilled and pollute the farms, there is a resultant decrease in some physicochemical properties of the soil. Petroleum products (AGO - Automtic gas oil; PMS - Premium motor spirit; DPK - Domestic petroleum kerosene) spillages have been suspected as a partial cause of environmental pollution in agricultural farm lands.

Communities therefore experience less productivity. The soil fertility status is decreased as well as the physicochemical properties and plant growth. oil spillage may be due to uncontrolled discharge through equipment failure, operational errors or by economic saboteurs or militants who willingly damage petroleum products pipelines. Farmers are mostly at disadvantage position because changes in physicochemical properties of the soil either affects yield positively or negatively. Physicochemical values below the critical level for a particular soil would discourage high yield in crops.

It has been suggested that poultry droppings be applied to soils previously contaminated with petroleum products. Some farmers instead prefer application of inorganic soils which is expensive and difficult to procure in most local farming communities. With the advantages of organic applications to the soil such as poultry droppings and compost, this experiment is designed to highlight and encourage the advantage of poultry dropping to a polluted ultisol. The poultry droppings applied would encourage organic farming to be practiced by farmers and increase their crop yields. The poultry droppings would likely improve soil conditions, fertility and increase physicochemical properties of the soil of the soil to values reasonable to support plant growth.

The aims of this experiment were therefore to carry out a physicochemical analysis of the ultisol before and after pollution with petroleum products and after application of poultry droppings and lastly to determine maize growth in the same soil. The goals of all these experimentations was to prove to local farmers that their polluted soils can be used for farming when they utilize poultry droppings that are easy to get and comparatively less expensive.

\section{Materials and Methods}

Experimental site

The experiment was sited in the Teaching and Research Farm of Benson Idahosa University, Benin City located within

1Department of Agriculture, Benson Idahosa University, Benin City, Nigeria. molindowa@yahoo.co.uk

${ }^{2}$ Department of Basic Sciences, Benson Idahosa University, Benin City, Nigeria 
latitude $5^{\circ} 05^{\prime}$ of Edo State, Southern Nigeria. The total plot size covered an area of $64 \mathrm{~m}^{2}$ and subdivided into 16 micro-plots of size $2 \mathrm{X} 2$ $\mathrm{m}^{2}$ each, arranged in a completely randomized design. Before treatment with petroleum products, soil samples were randomly collected from this pre-classified site from a depth of $0-15 \mathrm{~cm}$, air dried, ground, sieved with $2 \mathrm{~mm}$ mesh and physicochemically analysed.

\section{Experimental procedures}

The experiment was divided into three parts;

First part: Ten liters of each petroleum product was applied into $2 \mathrm{X} 2 \mathrm{~m} 2$ micro-plot and thoroughly mixed with soil while the control micro-plot had no petroleum product applied. All together there were four replicates giving a total of sixteen micro-plots. The micro-plots with polluted soil were left undisturbed for two weeks to allow incubation processes to take place. Soil samples were later collected from each plot, prepared and analysed for physicochemical properties.

Second part: On each of the previously polluted micro-plots, $2 \mathrm{~kg}$ of pre analysed poultry droppings was applied and thoroughly mixed and remained undisturbed for two weeks incubation. Later soil samples were collected and physicochemical properties determined.

Third part: Maize was planted in each of the micro-plots where poultry droppings had earlier been applied after two weeks incubation. Plant heights were measured at weekly intervals and mean determined. The biomass (harvested above ground plant parts) was determined at the fourth week after date of planting when the experiment was terminated.

\section{Laboratory analyses}

At different times three sets of soil samples were collected for physicochemical analyses. Soil samples were collected before application of petroleum products, after pollution and lastly after application of poultry droppings and allowed to incubate for two weeks. Soil samples collected at each stage of the experiment were air dried ground and sieved with $2 \mathrm{~mm}$ mesh before physicochemical analyses were carried out following routine methods.Particle size was determined according to the principle of particle size and sedimentation using hydrometer for reading (Anderson and Ingram, 1993). Soil $\mathrm{pH}$ was determined electrometrically following the procedure outlined by Mylavarapus and Kennelley (2002). Organic carbon and matter were determined by the wet dichromate acid oxidation method (Nelson and Sommers, 1982). Total nitrogen was determined using the macrokjeldhal method (Bremmer and Mulvaney, 1982). Nitrate-nitrogen was determined electrometrically using the phenol2-4-disulfonic acid method (Jackson, 1970). Available Phosphorus by the Bray P, (Olsen and Sommers, 1982) method, and color developed in soil extract using ascorbic acid method (Murphy and Riley, 1962). Excahngeable bases (K, $\mathrm{Ca}, \mathrm{Mg}, \mathrm{Na}$ ) were determined using the neutral $1 \mathrm{~N} \mathrm{KCl}$ (Thomas, 1982) and determined by titration using $0.05 \mathrm{~N} \mathrm{NaOH}$ using phenolphthalene indicator. The effective cation exchange capacity (ECEE) was derived from the summation of the exchangeable bases and exchangeable acidity (Chapman, 1965). The extractable micronutrients ( $\mathrm{Mn}, \mathrm{Fe}, \mathrm{Zn}, \mathrm{Cu}$ ) were extracted with $0.1 \mathrm{~N} \mathrm{HCl}$ (Viets and Boawn, 1965) and determined with atomic absorption spectrophotometer.

\section{Plant growth determination}

Plant heights were measured at weekly intervals to estimate plant growth for four weeks, the mean height was taken. Biomass was determined at the end of the fourth week from the date of planting and the mean value recorded. All data was subjected to statistical analysis (Little and Hill, 1978).

\section{Results}

Prior to the imposition of the experimental treatments i.e by pollution of the soil with different petroleum products and later by the addition of poultry droppings, the physicochemical properties of the ultisol were determined. The result is shown in table 1. From the result obtained major nutrients such as nitrogen, potassium and phosphorus had the following values; $\mathrm{N}=1.80 \mathrm{gkg}-1 ; \mathrm{P}=$ 12.85 mgkg- $1 ; \mathrm{K}=0.19$ cmolkg-1. When compared to their critical values, $\mathrm{N}=1.50-$ 2.00gkg-1 (Sobulo and Osinome, !981); $\mathrm{P}=$ 10.00 - 16.00 mgkg-1 (Agboola and Corey, 1973; Adeoye and Agboola, 1985); K = 0.16 0.20 cmolkg-1 (Hunters, 1975) for Southern Nigerian soils, the soil was therefore relatively fertile.

Table 2 shows values of physicochemical properties of the ultisol after polluted with the different petroleum products. 
There was a marked decrease in the values when compared with the initial values (Table 1) before the soil was polluted. The values showed that each petroleum product had a peculiar effect on the soil. The determined properties of poultry droppings are shown in table 3. The major nutrients NPK were relatively high when compared with critical values obtained for Southern Nigerian soils. Table 4 shows values of some physicochemical properties obtained from the ultisol that had been previously polluted with different petroleum products then later treated with poultry droppings. The values were relatively higher than both of the soil previously polluted with petroleum products and the control soil that was never treated. Treating of the soil with poultry droppings might therefore be said to be a good soil conditioner and encourages increased soil fertility. Table 5 shows plant height and biomass from maize that was grown in the soil that has been treated with poultry dropping although previously polluted with the different petroleum products. The results showed that both plant heights and biomass were relatively higher in the treated soil when compared with those from the control.

\section{Discussion}

The ultisol which was polluted with the different petroleum products experienced a significant decrease $(p=0.05)$ in values of physicochemical properties obtained when compared with the initial values. This showed that pollution with petroleum products had adverse impact in the soil physicochemical properties. The decrease in physicochemical properties was most pronounced in soil polluted with AGO followed by that polluted with PMS and then least in that polluted with DPK. The variation of pollution caused by the different petroleum products might be due to the fact that their reaction in the soil was not the same, since all of them are not of the same constituents. Treatment of the soil by the addition of poultry droppings encouraged the improvement in the soil fertility status.

The values of physicochemical properties increased when compared to those of the polluted soil and the control. Poultry droppings increased physicochemical properties of the soil as follows: Where DPK was the pollutant and poultry droppings added is where the highest values were obtained, followed by PMS and lastly by AGO previously polluted soil. The growth parameters (plant height and biomass) were significantly highest $(\mathrm{p}=0.05)$ in soil treated with poultry droppings than the polluted and control soils respectively. The soil that was not polluted but only treated with poultry droppings produced the tallest plants with highest biomass; indicating that poultry droppings had an encouraged impact on the soil fertility which was observed in the measured parameters. When plant heights and biomass were compared in soil polluted with different petroleum products, then later treated with the poultry droppings, the following trend was observed; plant height and biomass from DPK > PMS > AGO respectively.

\section{Conclusion}

This experiment has shown that different petroleum products have varied proportion of adverse impact on soil. As proved by the various values of physicochemical properties when comparisons were made between initial values before and after pollution indicated that the petroleum product encouraged this reduction in soil physicochemical properties.

However addition of poultry droppings to the polluted soil improves the soil fertility in terms of the increased value in the soil physicochemical properties. Therefore farmers in locations with ultisols should be encouraged to apply poultry droppings to their farm lands previously polluted by different petroleum products. This would contribute to improved soil fertility and eventually encourage increased food production. With the current trend in organic farming, poultry droppings are therefore a very good source of organic materials that would contribute to increased food production in locations having contaminated and polluted soil. 


\section{References}

Adeoye, G.O. and A.A.Agboola, 1985. Critical levels for soil $\mathrm{pH}$, available $\mathrm{P}, \mathrm{K}, \mathrm{Zn}$ and maize leaf content of $\mathrm{P}, \mathrm{Cu}$ and $\mathrm{Mn}$ in sedimentary soils of Southwestern Nigeria. Fertilizer Resource 6(1): 65

Agboola, A.A. and R.B. Corey, 1973. The relationship between soil $\mathrm{pH}$, organic matter, available $\mathrm{P}$, exchangeable $\mathrm{K}, \mathrm{Ca}, \mathrm{Mg}$ and 9 elements in the maize tissue. Soil Science., 115(5): 367 - 375.

Bremmer, J.M. and C.S. Mulvaney, 1982. Nitrogen-Total. Methods of soil analysis. In: Page, A.L.et al. (Eds.). $2^{\text {nd }}$ Edn. Part 2. Agronomy Monograph 9. American Society of Agronomy and Soil Science Society of America, Madison, Wisconsin, pp 595 - 624 Chapman, H.D. 1965. Cation Exchange capacity. In: Black, C.A. (Ed.). methods of Soil Analysis. Part III. Agronomy. American Society of Agronomy. Incorporate Publisher, Madison, Wisconsin, 9: 891901.

Hunter, A.H.J. 1975. Laboratory and Greenhouse techniques for nutrient survey to determine the soil amendments required for optimum plant growth. International soil fertilizer environmental improvement project, North Carolina State University, Raleigh North Carolina.

Jackson, M.L. 1970. Nitrate-nitrogen. Soil Chemical Analysis. $6^{\text {th }}$ Edn. Prentice-Hall Incorporation. Englewood Cliffs, New York, pp $326-330$.

Little, T.M. and F.J. Hills. 1978. Agricultural Experimentation, Design and Analysis. John Wiley and Sons. New York, pp 350.
Murphy, J. and J.K.P. Riley, 1962. A modified single solution method for the determination of phosphorus in natural waters. Analyt.Chem.Acta. 27; 31 - 36.

Mylavarapu, R.S. and E.D. Kennelley. 2002. UF/IFAS Extension Soil Testing laboratory (ESTL). Analytical procedures and Training Manual pp 350.

Nelson, D.W. and L.E. Sommers. 1982. Total carbon, Organic matter. In: Page, A.L et al. (Eds.). Methods of soil Analysis Part 2. Agronomy Monograph 9. $2^{\text {nd }}$ Edn. American Society for Agronomy and Soil Science Society of America. Madison, Wisconsin, pp $539-579$.

Olsen, S.R. and L.E. Sommers. 1982. Phosphorus. In Page, A.L.et al. (Eds.). Methods of soil Analysis Part 2. Agronomy Monograph 9. $2^{\text {nd }}$ Edn. American Society for Agronomy and Soil Science Society of America. Madison, Wisconsin, pp 403 - 430.

Sobulo, R.A. and A.O. Osiname. 1981. Soils and Fertilizer use in Western Nigeria. Resource Bulletin. No. 11. Institute of Agricultural research and Training, University of Ife, Nigeria.

Thomas, G.W. 1982. Exchangeable Cations. In Page, A.L.et al. (Eds.). Methods of soil Analysis Part 2. Agronomy Monograph 9. $2^{\text {nd }}$ Edn. American Society for Agronomy and Soil Science Society of America. Madison, Wisconsin, pp $159-165$.

Viets, F.G.J and L.C. Boawn. 1965. 0.1 N HCl Ectraction Methods. Methods of Soil Analysis, Part 2. No. 9. Agronomy Soil. In Black, C.A. et al. (Eds.). American Society of Agronomy. Madison, Wisconsin, pp $1098-1100$. 
Table 1 Values of physicochemical properties of ultisol before contamination with different petroleum products.

\begin{tabular}{|c|c|}
\hline Physicochemical Properties & Values (0 - $15 \mathrm{~cm}$ depth) \\
\hline Sand (\%) & 76.00 \\
\hline Silt (\%) & 2.00 \\
\hline Clay $(\%)$ & 22.00 \\
\hline Textural class & Sand clay loam \\
\hline $\mathrm{pH}\left(\mathrm{H}_{2} \mathrm{O}\right)$ & 6.70 \\
\hline $\mathrm{pH}\left(\mathrm{CaCl}_{2}\right)$ & 6.10 \\
\hline Organic $-\mathrm{C}\left(\mathrm{g} \mathrm{kg}^{-1}\right)$ & 15.50 \\
\hline Organic $-\mathrm{M}\left(\mathrm{g} \mathrm{kg}^{-1}\right)$ & 13.90 \\
\hline Total - N (g kg-1) & 1.80 \\
\hline $\mathrm{C}: \mathrm{N}$ ratio & $9: 1$ \\
\hline Nitrate $-\mathrm{N}\left(\mathrm{mg} \mathrm{kg}^{-1}\right)$ & 7.50 \\
\hline Available $-\mathrm{P}\left(\mathrm{mg} \mathrm{kg}^{-1}\right)$ & 12.85 \\
\hline \multicolumn{2}{|l|}{ Exchangeable bases $\left(\mathrm{cmol} \mathrm{kg}^{-1}\right)$} \\
\hline K & 0.19 \\
\hline $\mathrm{Ca}$ & 0.35 \\
\hline $\mathrm{Mg}$ & 0.50 \\
\hline $\mathrm{Na}$ & 0.11 \\
\hline Total Exchangeable bases TEB $\left(\mathrm{cmol} \mathrm{kg}^{-1}\right)$ & 1.15 \\
\hline Exchangeable Acidity EA $\left(\mathrm{cmol} \mathrm{kg}^{-1}\right)$ & 0.45 \\
\hline E.C.E.E.C. $\left(\mathrm{cmol} \mathrm{kg}^{-1}\right)$ & 1.60 \\
\hline \multicolumn{2}{|l|}{ Extractable Micronutrients $\left(\mathrm{mg} \mathrm{kg}^{-1}\right)$} \\
\hline $\mathrm{Mn}$ & 6.50 \\
\hline $\mathrm{Cu}$ & 2.30 \\
\hline $\mathrm{Zn}$ & 3.40 \\
\hline $\mathrm{Fe}$ & 5.10 \\
\hline
\end{tabular}


Table 2 Values of some physicochemical properties of the ultisol after contamination with different petroleum products

\begin{tabular}{|c|c|c|c|c|c|c|}
\hline \multirow[t]{2}{*}{ Physicochemical Properties } & \multicolumn{6}{|c|}{ Values $(0-15 \mathrm{~cm}$ depth $)$} \\
\hline & A & $\mathrm{B}$ & $\mathrm{C}$ & $\mathrm{D}$ & Mean & LSD 5\% \\
\hline Sand (\%) & 77.00 & 78.50 & 77.00 & 76.40 & 77.40 & 1.77 \\
\hline Silt (\%) & 1.80 & 2.00 & 2.30 & 2.50 & 2.15 & 0.60 \\
\hline Clay (\%) & 21.20 & 19.50 & 20.00 & 21.10 & 20.45 & 1.92 \\
\hline $\mathrm{pH}\left(\mathrm{H}_{2} \mathrm{O}\right)$ & 5.50 & 5.00 & 4.80 & 4.90 & 5.05 & 0.61 \\
\hline $\mathrm{pH}\left(\mathrm{CaCl}_{2}\right)$ & 4.80 & 4.32 & 4.20 & 4.10 & 4.36 & 0.60 \\
\hline Organic $-\mathrm{C}\left(\mathrm{g} \mathrm{kg}^{-1}\right)$ & 9.40 & 5.80 & 7.12 & 7.40 & 6.18 & 4.05 \\
\hline Organic $-\mathrm{M}\left(\mathrm{g} \mathrm{kg}^{-1}\right)$ & 10.15 & 6.54 & 7.00 & 7.90 & 7.89 & 3.14 \\
\hline Total - N (g kg-1) & 0.89 & 0.40 & 0.45 & 0.52 & 0.56 & 0.43 \\
\hline $\mathrm{C}: \mathrm{N}$ ratio & 11:1 & $17: 1$ & 15:1 & $14: 1$ & & \\
\hline Nitrate $-\mathrm{N}\left(\mathrm{mg} \mathrm{kg}^{-1}\right)$ & 8.37 & 6.50 & 6.80 & 7.10 & 7.19 & 0.25 \\
\hline Available - $\mathrm{P}\left(\mathrm{mg} \mathrm{kg}^{-1}\right)$ & 10.20 & 5.00 & 5.90 & 6.68 & 6.94 & 4.45 \\
\hline \multicolumn{7}{|l|}{ Exchangeable bases $\left(\mathrm{cmol} \mathrm{kg}^{-1}\right)$} \\
\hline K & 0.18 & 0.08 & 0.10 & 0.12 & 0.12 & 0.08 \\
\hline $\mathrm{Ca}$ & 0.37 & 0.20 & 0.23 & 0.30 & 0.27 & 0.14 \\
\hline $\mathrm{Mg}$ & 1.34 & 0.56 & 0.70 & 0.78 & 0.84 & 0.66 \\
\hline $\mathrm{Na}$ & 0.15 & 0.09 & 0.11 & 0.14 & 0.12 & 0.05 \\
\hline Total Exchangeable bases $\left(\mathrm{cmol} \mathrm{kg}^{-1}\right)$ & 2.04 & 0.93 & 1.14 & 1.34 & 1.36 & 0.94 \\
\hline Exchangeable Acidity $\left(\mathrm{cmol} \mathrm{kg}^{-1}\right)$ & 1.60 & 1.12 & 1.13 & 1.15 & 1.25 & 0.45 \\
\hline E.C.E.E.C. $\left(\mathrm{cmol} \mathrm{kg}^{-1}\right)$ & 3.64 & 2.06 & 2.27 & 2.49 & 2.61 & 1.38 \\
\hline \multicolumn{7}{|l|}{ Extractable Micronutrients $\left(\mathrm{mg} \mathrm{kg}^{-1}\right)$} \\
\hline $\mathrm{Mn}$ & 5.40 & 4.35 & 4.50 & 5.00 & 4.81 & 0.94 \\
\hline $\mathrm{Cu}$ & 2.50 & 2.00 & 2.10 & 2.35 & 2.23 & 0.44 \\
\hline $\mathrm{Zn}$ & 3.00 & 2.15 & 2.00 & 2.25 & 2.35 & 0.87 \\
\hline $\mathrm{Fe}$ & 4.50 & 3.60 & 3.80 & 4.00 & 3.97 & 0.75 \\
\hline
\end{tabular}

*A = CS - Control soil; $\mathrm{B}=\mathrm{AGO}+\mathrm{S}-$ Automated gas oil added to soil $\mathrm{C}=\mathrm{PMS}+\mathrm{S}-$ Premium motor spirit added to soil; $\mathrm{D}=\mathrm{DPK}+\mathrm{S}-$ Domestic petroleum kerosene added to soil. 
Table 3 Values of some physicochemical properties of the pre-analyzed poultry droppings

\begin{tabular}{|c|c|}
\hline Physicochemical Properties & Values \\
\hline $\mathrm{pH}\left(\mathrm{H}_{2} \mathrm{O}\right)$ & 7.20 \\
\hline $\mathrm{pH}\left(\mathrm{CaCl}_{2}\right)$ & 6.50 \\
\hline Organic $-\mathrm{C}\left(\mathrm{g} \mathrm{kg}^{-1}\right)$ & 19.50 \\
\hline Organic $-\mathrm{M}\left(\mathrm{g} \mathrm{kg}^{-1}\right)$ & 21.00 \\
\hline Total - N (g kg-1) & 3.35 \\
\hline $\mathrm{C}: \mathrm{N}$ ratio & $6: 1$ \\
\hline Nitrate $-\mathrm{N}\left(\mathrm{mg} \mathrm{kg}^{-1}\right)$ & 17.20 \\
\hline Available $-\mathrm{P}\left(\mathrm{mg} \mathrm{kg}^{-1}\right)$ & 18.10 \\
\hline \multicolumn{2}{|l|}{ Exchangeable bases $\left(\mathrm{cmol} \mathrm{kg}^{-1}\right)$} \\
\hline $\mathrm{K}$ & 0.65 \\
\hline $\mathrm{Ca}$ & 2.30 \\
\hline $\mathrm{Mg}$ & 1.22 \\
\hline $\mathrm{Na}$ & 0.44 \\
\hline Total Exchangeable bases TEB $\left(\mathrm{cmol} \mathrm{kg}^{-1}\right)$ & 4.61 \\
\hline Exchangeable Acidity EA ( $\left.\mathrm{cmol} \mathrm{kg}^{-1}\right)$ & 1.70 \\
\hline E.C.E.E.C. $\left(\mathrm{cmol} \mathrm{kg}^{-1}\right)$ & 6.31 \\
\hline \multicolumn{2}{|l|}{ Extractable Micronutrients $\left(\mathrm{mg} \mathrm{kg}^{-1}\right)$} \\
\hline $\mathrm{Mn}$ & 1.25 \\
\hline $\mathrm{Cu}$ & 0.70 \\
\hline $\mathrm{Zn}$ & 0.45 \\
\hline $\mathrm{Fe}$ & 0.60 \\
\hline
\end{tabular}


Table 4 Values of some physicochemical properties of the ultisol previously polluted with different petroleum products and later treated with poultry droppings

\begin{tabular}{|c|c|c|c|c|c|c|}
\hline \multirow[t]{2}{*}{ Physicochemical Properties } & \multicolumn{6}{|c|}{ Values $(0-15 \mathrm{~cm}$ depth $)$} \\
\hline & A & $\mathrm{B}$ & $\mathrm{C}$ & $\mathrm{D}$ & Mean & LSD 5\% \\
\hline Sand (\%) & 78.50 & 78.10 & 77.80 & 76.90 & 77.82 & 1.33 \\
\hline Silt (\%) & 1.90 & 2.50 & 2.30 & 2.80 & 2.37 & 0.74 \\
\hline Clay (\%) & 19.60 & 19.40 & 19.90 & 20.30 & 19.80 & 0.76 \\
\hline Textural Class & SCL & SCL & SCL & SCL & & \\
\hline $\mathrm{pH}\left(\mathrm{H}_{2} \mathrm{O}\right)$ & 6.95 & 6.75 & 6.80 & 6.60 & 6.77 & 0.28 \\
\hline $\mathrm{pH}\left(\mathrm{CaCl}_{2}\right)$ & 6.40 & 6.30 & 6.25 & 6.00 & 6.23 & 0.21 \\
\hline Organic $-\mathrm{C}\left(\mathrm{g} \mathrm{kg}^{-1}\right)$ & 10.90 & 8.90 & 9.50 & 10.40 & 9.92 & 1.75 \\
\hline Organic $-\mathrm{M}\left(\mathrm{g} \mathrm{kg}^{-1}\right)$ & 12.20 & 9.50 & 10.40 & 11.60 & 10.93 & 2.37 \\
\hline Total - N (g kg-1) & 1.95 & 1.10 & 1.30 & 1.55 & 1.47 & 0.69 \\
\hline $\mathrm{C}: \mathrm{N}$ ratio & $6: 1$ & $8: 1$ & $7: 1$ & $7: 1$ & & \\
\hline Nitrate $-\mathrm{N}\left(\mathrm{mg} \mathrm{kg}^{-1}\right)$ & 11.20 & 9.35 & 10.40 & 11.60 & 10.63 & 1.94 \\
\hline Available - $\mathrm{P}\left(\mathrm{mg} \mathrm{kg}^{-1}\right)$ & 10.90 & 8.00 & 9.10 & 10.40 & 9.60 & 2.56 \\
\hline \multicolumn{7}{|l|}{ Exchangeable bases $\left(\mathrm{cmol} \mathrm{kg}^{-1}\right)$} \\
\hline $\mathrm{K}$ & 0.25 & 0.15 & 0.17 & 0.19 & 0.19 & 0.11 \\
\hline $\mathrm{Ca}$ & 0.48 & 0.31 & 0.39 & 0.40 & 0.39 & 0.13 \\
\hline $\mathrm{Mg}$ & 1.50 & 0.90 & 1.10 & 1.25 & 1.18 & 0.48 \\
\hline $\mathrm{Na}$ & 0.18 & 0.12 & 0.14 & 0.17 & 0.15 & 0.05 \\
\hline Total Exchangeable bases $\left(\mathrm{cmol} \mathrm{kg}^{-1}\right)$ & 2.41 & 1.48 & 1.80 & 2.01 & 1.92 & 0.07 \\
\hline Exchangeable Acidity $\left(\mathrm{cmol} \mathrm{kg}^{-1}\right)$ & 1.95 & 1.30 & 1.65 & 1.80 & 1.67 & 0.54 \\
\hline E.C.E.E.C. $\left(\mathrm{cmol} \mathrm{kg}^{-1}\right)$ & 4.36 & 2.78 & 3.45 & 3.81 & 3.60 & 1.29 \\
\hline \multicolumn{7}{|l|}{ Extractable Micronutrients $\left(\mathrm{mg} \mathrm{kg}^{-1}\right)$} \\
\hline $\mathrm{Mn}$ & 5.60 & 4.85 & 5.20 & 5.70 & 5.33 & 0.76 \\
\hline $\mathrm{Cu}$ & 2.60 & 2.30 & 2.60 & 2.95 & 2.61 & 0.52 \\
\hline $\mathrm{Zn}$ & 3.10 & 2.40 & 2.85 & 3.20 & 2.88 & 0.70 \\
\hline $\mathrm{Fe}$ & 4.70 & 3.90 & 4.15 & 4.60 & 4.33 & 0.73 \\
\hline
\end{tabular}

*A = CS - Control soil; $\mathrm{B}=\mathrm{AGO}+\mathrm{S}-$ Automated gas oil added to soil; $\mathrm{C}=\mathrm{PMS}+\mathrm{S}-$ Premium motor spirit added to soil; $\mathrm{D}=\mathrm{DPK}+\mathrm{S}-$ Domestic petroleum kerosene added to soil. 
Table 5 Mean of plant height and biomass of maize grown in soil previously polluted with petroleum products then later treated with poultry droppings

\begin{tabular}{|l|l|l|}
\hline TREATMENTS & \multicolumn{2}{|c|}{ PARAMETERS } \\
\hline CS & Plant Heights (cm) & Biomass $(\mathrm{g})$ \\
\hline PD + CS & 46.00 & 34.00 \\
\hline SAGO & 51.50 & 40.70 \\
\hline PD + SAGO & 32.60 & 26.20 \\
\hline SPMS & 41.50 & 32.00 \\
\hline PD + SPMS & 34.00 & 28.50 \\
\hline SPDK & 44.10 & 34.40 \\
\hline PD + SPDK & 37.40 & 30.80 \\
\hline Mean & 48.50 & 36.10 \\
\hline LSD 5\% & 48.13 & 32.90 \\
\hline
\end{tabular}

$\mathrm{CS}=\mathrm{Control}$ soil PD+CS = poultry droppings added to control soil; $\mathrm{SAGO}=$ Soil polluted with AGO;

$\mathrm{PD}+\mathrm{SAGO}=$ Poultry droppings added to soil polluted with AGO; SPMS = Soil polluted with PMS;

PD + SPMS = Poultry droppings added to soil polluted with PMS; SDPK = Soil polluted with DPK; PD

+ DPK $=$ Poultry droppings added to soil polluted with DPK. 